\title{
Chemical Composition Assessment by Wavelength Dispersive X-Ray Fluorescence of Agricultural Soils in the Mining Town of Moanda, Gabon
}

\author{
Albert Novy Messi Me Ndong*, Adam Bouraïma, Crislain Bissielou, \\ Jean-Jacques Anguile, Thomas Makani
}

Laboratoire de Chimie des Matériaux Inorganique, Université des Sciences et Techniques de Masuku, Franceville, Gabon

Email: *messinovy@gmail.com

How to cite this paper: Messi Me Ndong, A.N., Bouraïma, A., Bissielou, C., Anguile, J.J. and Makani, T. (2021) Chemical Composition Assessment by Wavelength Dispersive X-Ray Fluorescence of Agricultural Soils in the Mining Town of Moanda, Gabon. Journal of Agricultural Chemistry and Environment, 10, 345-358.

https://doi.org/10.4236/jacen.2021.103022

Received: June 16, 2021

Accepted: July 31, 2021

Published: August 3, 2021

Copyright $\odot 2021$ by author(s) and Scientific Research Publishing Inc. This work is licensed under the Creative Commons Attribution International License (CC BY 4.0).

http://creativecommons.org/licenses/by/4.0/

\begin{abstract}
This work focuses on the analysis of the chemical composition of soils dedicated to agriculture in order to assess the impacts of manganese mining activity in the city of Moanda in South-East Gabon. The result of the analysis obtained using wavelength dispersive X-ray fluorescence revealed the presence of twenty-seven elements in the seventeen soil samples collected namely: $\mathrm{Na}$, $\mathrm{K}, \mathrm{Rb}, \mathrm{Mg}, \mathrm{Ca}, \mathrm{Sr}, \mathrm{Ba}, \mathrm{Ti}, \mathrm{Fe}, \mathrm{Co}, \mathrm{Ni}, \mathrm{Cu}, \mathrm{Zn}, \mathrm{Y}, \mathrm{Zr}, \mathrm{Nb}, \mathrm{Cr}, \mathrm{Mn}, \mathrm{Al}, \mathrm{O}, \mathrm{C}, \mathrm{P}, \mathrm{S}$, $\mathrm{Si}, \mathrm{I}, \mathrm{Ac}$ and $\mathrm{Th}$. Iron $(\mathrm{Fe})$, aluminum $(\mathrm{Al})$ and manganese $(\mathrm{Mn})$ were respectively higher. The practice of agriculture near mining sites is not without risks for the quality of agricultural products and the health of the population.
\end{abstract}

\section{Keywords}

Metallic Trace Elements, X-Ray Fluorescence, Agricultural Soils

\section{Introduction}

The intensification of manganese mining activity in the city of Moanda in recent years is supported by the ever-increasing demand of the world market for manganese. In 2019, Gabon achieved annual production of 6.1 million tonnes against 5.2 million tonnes in 2018, an increase of 17\% [1] [2]. Despite the economic importance of this activity, the fact remains that most of the population of Moanda lives below the poverty line. This poverty forces these people to resort to working the land by practicing rural subsistence agriculture. Agriculture is not without risk in this region due to the proximity of the fields and the various mining 
activities which can be at the origin of environmental pollution through various scenarios and more precisely for this study pollution agricultural soils. This pollution results in the presence of metallic trace elements at abnormal concentrations on the surface or in the first meters of soil [3] [4].

Monitoring soil quality is an environmental and public health issue because the soil in the interface position indeed plays a primordial role in the balance of ecosystems: in climate change, the protection of the quality of the resource by water and as a support for agricultural production [5].

The absence of public data and soil protection policies so far has little been taken into account in public policies in our country. This shows the need for the implementation of this study to better orient the action of policies in terms of environmental monitoring [6].

\section{Material and Methods}

\section{Study zone}

The study was carried out in a region of south-eastern Gabon in the HautOgooué province and more precisely in the mining town of Moanda geo-located at 571 meters above sea level, between $\left(1^{\circ} 33^{\prime} 25^{\prime \prime}\right.$ South latitude and $13^{\circ} 13^{\prime} 40^{\prime \prime}$ East) [7]. The region belongs to a non-metamorphic detrital and volcano-sedimentary series of the Francevillian which outcrops in the south-eastern quarter of Gabon [8]. The climate of the region is relatively similar throughout the country which is characterized by a humid equatorial climate with average temperatures of $24^{\circ} \mathrm{C}$ and average annual precipitation of between $(800-2000 \mathrm{~mm})$ [9]. Mining takes place in an open pit mine on the Bangombé plateau, located above the city. It is one of the largest deposits in the world, with a manganese content of roughly $30 \%$ - 46\%, one of the highest on the market [10]. Since 2019, the production capacity of the Moanda mine has been increased, making Gabon the world's second producer of high-grade manganese with 4.8 MT of manganese ore produced in 2019. The landscape of Moanda is recognizable by a mixture savannas and groves, plains, cornices and sandstone plateaus. The relief of Bangombé has become a landscape of small black sterile hills of manganese very poor in minerals and very acidic [11].

\section{Sampling and sample preparation}

Sampling took place during the month of January to June 2016. It was a shallow sampling. In the case of sampling agricultural soils, the depth relevant to the objectives is that between $(0-15 \mathrm{~cm})$ which constitutes the rhizosphere (the surface explored by the roots). The soil blocks were removed using a 5-point stainless steel helical auger forming a cross on each field. The soils of each site were homogenized in order to have a representative sample from each site [12] [13].

The collected soil samples were placed in labeled plastic bags, transported to the laboratory.

Drying in an oven for 24 hours at an average temperature of $105^{\circ} \mathrm{C}$ was carried out in order to standardize the residual humidity level and to facilitate bet- 
ter grinding. The weighing after drying made it possible to determine the water contents for each sample. The samples were weighed fresh and after drying to determine the mass water content. This content noted $W$ is calculated using Equation (1)

$$
W=\frac{M_{f}-M_{s}}{M_{f}} \times 100
$$

$M_{f}=$ fresh leaf mass; $M_{s}=$ dry leaf mass.

The dried samples were ground in porcelain mortars, the whole sieved to keep only particles of $2 \mathrm{~mm}$ of particle size [14] [15].

For analysis, the preparation of the pellets and the determination of the total elements were carried out at the CNRST-UATRS Division in Morocco in early July 2016.

\section{Mineralogical analysis of soils}

For the mineralogical analysis of soils, wavelength dispersive X-ray fluorescence was the required technique. It allows simultaneous qualitative and quantitative analysis of almost all elements ranging from Boron $(Z=5)$ to Uranium $(Z=92)$ in an unknown sample [16] [17] [18].

The conversion of the concentration of an element in the pellet (expressed in \%) into the concentration of an element $i$ in the dry matter (expressed in $\mathrm{mg} / \mathrm{kg}$ or $\mathrm{ppm}$ ) is given by Equation (2):

$$
C_{S i}=2 \times 10^{4} \times C_{p_{i}}(\%)
$$

$C_{S i}=$ Concentration of element $i$ in the dry matter (in $\mathrm{mg} / \mathrm{kg}$ or $\mathrm{ppm}$ ).

$C_{p_{i}}=$ Concentration of an element $i$ in the pellet in (\%).

\section{Results and Discussion}

The GPS coordinates of the different sites have been listed in a table (Table 1). Then which points were inserted into a map using Google Earth software (Figure 1).

The results of the weighing as well as the water contents (W) of the soil samples, before and after passage in the oven are presented in Table 2.

We can, in view of these results, say that the average water content (W) of the soils is of the order of 7\% relative to the mass of the fresh sample. This low water content in the soils could be explained by the sampling period which corresponded to the short dry season.

\begin{tabular}{|c|c|c|c|c|c|c|c|c|c|}
\hline & Site 1 & Site 2 & Site 3 & Site 4 & Site 5 & Site 6 & Site 7 & Site 8 & Site 9 \\
\hline S & $01^{\circ} 35^{\prime} 10.6^{\prime \prime}$ & $01^{\circ} 33^{\prime} 56.4^{\prime \prime}$ & $01^{\circ} 34^{\prime} 54.3^{\prime \prime}$ & $01^{\circ} 33^{\prime} 03.1^{\prime \prime}$ & $01^{\circ} 32^{\prime} 44.8^{\prime \prime}$ & $01^{\circ} 32^{\prime} 00.0^{\prime \prime}$ & $01^{\circ} 32^{\prime} 00.0^{\prime \prime}$ & $01^{\circ} 31^{\prime} 26.9^{\prime \prime}$ & $01^{\circ} 29^{\prime} 63.8^{\prime \prime}$ \\
\hline \multirow[t]{2}{*}{$\mathrm{E}$} & $013^{\circ} 14^{\prime} 42.6^{\prime \prime}$ & $013^{\circ} 14^{\prime} 09.4^{\prime \prime}$ & $013^{\circ} 14^{\prime} 06.3^{\prime \prime}$ & $013^{\circ} 12^{\prime} 45.1^{\prime \prime}$ & $013^{\circ} 12^{\prime} 13.8^{\prime \prime}$ & $013^{\circ} 1^{\prime} 21.3^{\prime \prime}$ & $013^{\circ} 1^{\prime} 21.3^{\prime \prime}$ & $013^{\circ} 12^{\prime} 73.1^{\prime \prime}$ & $013^{\circ} 13^{\prime} 98.2^{\prime \prime}$ \\
\hline & Site 10 & Site 11 & Site 12 & Site 13 & Site 14 & Site 15 & Site 16 & Site 17 & \\
\hline S & $01^{\circ} 29^{\prime} 83.0^{\prime \prime}$ & $01^{\circ} 32^{\prime} 173.5^{\prime \prime}$ & $01^{\circ} 34^{\prime} 75.5^{\prime \prime}$ & $01^{\circ} 39^{\prime} 99.1^{\prime \prime}$ & $01^{\circ} 33^{\prime} 81.5^{\prime \prime}$ & $01^{\circ} 37^{\prime} 20.3^{\prime \prime}$ & $01^{\circ} 33^{\prime} 57.6^{\prime \prime}$ & $01^{\circ} 28^{\prime} 62.2^{\prime \prime}$ & \\
\hline $\mathrm{E}$ & $013^{\circ} 14^{\prime} 09.8^{\prime \prime}$ & $013^{\circ} 13^{\prime} 00.2^{\prime \prime}$ & $013^{\circ} 09^{\prime} 84.1^{\prime \prime}$ & $013^{\circ} 11^{\prime} 59.3^{\prime \prime}$ & $013^{\circ} 12^{\prime} 67.6^{\prime \prime}$ & $013^{\circ} 15^{\prime} 67.1^{\prime \prime}$ & $013^{\circ} 12^{\prime} 86.3^{\prime \prime}$ & $013^{\circ} 11^{\prime} 22.2^{\prime \prime}$ & \\
\hline
\end{tabular}

Table 1. GPS Coordinates of the thirteen sites of sampling in the study area. 


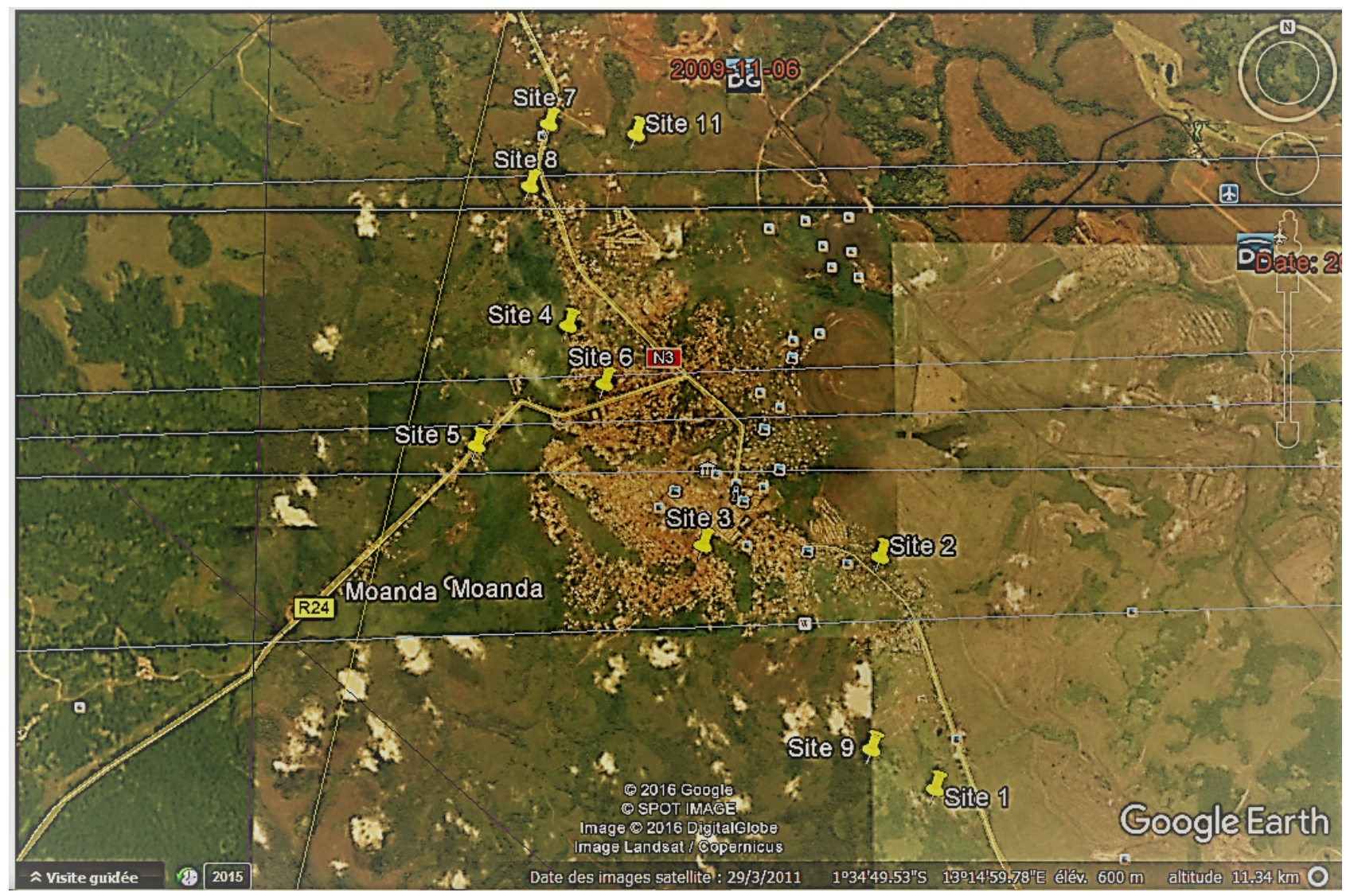

Figure 1. Geolocation of the sampling area (Moanda).

Table 2. Water content in agricultural soils (W\%).

\begin{tabular}{cccccccccccccccccccc}
\hline & Site & Site & Site & Site & Site & Site & Site & Site & Site & Site & Site & Site & Site & Site & Site & Site & Site & AVERAGE \\
AVERAGE STANDARD \\
DEVIATION
\end{tabular}

\section{Qualitative analysis}

Qualitative analysis by wavelength-dispersive $\mathrm{X}$-ray fluorescence of our agricultural soil samples identified a set of 22 oxides: $\mathrm{Fe}_{2} \mathrm{O}_{3}, \mathrm{Al}_{2} \mathrm{O}_{3}, \mathrm{MnO}_{2}, \mathrm{SiO}_{2}$, $\mathrm{P}_{2} \mathrm{O}_{5}, \mathrm{TiO}_{2}, \mathrm{~K}_{2} \mathrm{O}, \mathrm{MgO}, \mathrm{CaO}, \mathrm{NiO}, \mathrm{ZrO}_{2}, \mathrm{Nb}_{2} \mathrm{O}_{5}, \mathrm{Cr}_{2} \mathrm{O}_{3}, \mathrm{SrO}, \mathrm{ThO}_{2}, \mathrm{BaO}, \mathrm{SO}_{3}$, $\mathrm{Y}_{2} \mathrm{O}_{3}, \mathrm{CuO}, \mathrm{ZnO}, \mathrm{Na}_{2} \mathrm{O}, \mathrm{CoO}$, and 4 naturally free elements: I, Ac, Rb, C.

These chemical elements have been grouped as follows: the alkali metals namely: $\mathrm{Na}, \mathrm{K}$ and $\mathrm{Rb}$; alkaline earths: $\mathrm{Mg}, \mathrm{Ca}, \mathrm{Sr}$ and $\mathrm{Ba}$; the transition elements: $\mathrm{Ti}, \mathrm{Fe}, \mathrm{Co}, \mathrm{Ni}, \mathrm{Cu}, \mathrm{Zn}, \mathrm{Y}, \mathrm{Zr}, \mathrm{Nb}, \mathrm{Cr}$ and $\mathrm{Mn}$; the presence of $\mathrm{Al}$ is a metal not metalloid; The presence of non-metals namely: O, C, P, S and Si; detect halogen: I; two rare earths: Ac, Th. Among these elements, we note the main nutrients of the soil which are: metallic cations: calcium $(\mathrm{Ca})$, magnesium $(\mathrm{Mg})$, potassium $(\mathrm{K})$, sodium $(\mathrm{Na})$ and the main anions: phosphorus $(\mathrm{P})$. These nutrients contri- 
bute to biological functioning and are referred to as major building blocks in animals and plants [5]. We have the presence of chemical elements whose low content is recognized as responsible for the deficiency of plants or their phytotoxicity: These are the so-called essential elements: $\mathrm{Fe}, \mathrm{Mn}, \mathrm{Zn}, \mathrm{Cu}$ and $\mathrm{Co}$ and other elements considered beneficial for the plant: $\mathrm{Cr}, \mathrm{I}, \mathrm{Ni}, \mathrm{Rb}, \mathrm{Se}, \mathrm{Si}, \mathrm{Sr}$ and $\mathrm{Ti}$. Its last two categories are also called trace elements. The absence of pollutants in all the soil samples analyzed, i.e. elements whose essential character for living beings has not yet been demonstrated [19]. This absence may be linked to the practice of essentially artisanal agriculture without the use of fertilizers and pesticides.

The mineralogical concentrations (in \% dry mass) of the major elements and trace elements in the agricultural soils of Moanda are presented in Table 3 and Table 4. The average contents of major elements in the sampled soils $\mathrm{Fe}_{2} \mathrm{O}_{3}$ (23.90), $\mathrm{Al}_{2} \mathrm{O}_{3}$ (16.26), $\mathrm{MnO}_{2}$ (4.17), $\mathrm{SiO}_{2}$ (38.98), $\mathrm{P}_{2} \mathrm{O}_{5}$ (0.18), $\mathrm{TiO}_{2}$ (2.46) are higher than the contents found at the level of the earth's crust, ie 5.00; 8.10; 0.10; 27.70; $0.11 ; 0.44$ for $\mathrm{Fe}_{2} \mathrm{O}_{3}, \mathrm{Al}_{2} \mathrm{O}_{3}, \mathrm{MnO}_{2}, \mathrm{SiO}_{2}, \mathrm{P}_{2} \mathrm{O}_{5}, \mathrm{TiO}_{2}$; except for the concentrations of $\mathrm{MgO}(0.27), \mathrm{K}_{2} \mathrm{O}(1.04)$ and $\mathrm{CaO}(0.44)$ in the agricultural soils of Moanda against 2.00; 2.50; 3.63 in the earth's crust [20]. The average contents of $\mathrm{Al}_{2} \mathrm{O}_{3}, \mathrm{MnO}_{2}$ and $\mathrm{Fe}_{2} \mathrm{O}_{3}$ are respectively 2, 4 and 5 times higher than those found in the earth's crust. The non-detection of $\mathrm{Mn}$ on the sites $(1,2,6,7$ and 8) corresponds to soil samples coming from plantations far from the town of Moanda, that is to say. Sites ( 1 and 2 ) corresponding to the soil samples taken on the Franceville-Moanda road; Sites (6, 7 and 8) for soil samples on the MoandaMounana road and site 12 on the Moanda-Bakoumba road. Detection of $\mathrm{Cu}$ (Sites 13 and 16), Co (Sites 3 and 11), Cr (Site 1), Zn (3, 7, 14 and 17) and Ni (1, $6,7,8,10,12$ and 16) would correspond to point pollution, the exact origin of which is not known, but most of which are due to natural contamination in the vicinity of mining deposits and to atmospheric pollution.

Table 3. Concentration (in \%) of major elements in agricultural soils of Moanda.

\begin{tabular}{|c|c|c|c|c|c|c|c|c|c|c|c|c|c|c|c|c|c|c|}
\hline & Site 1 & Site 2 & Site 3 & Site 4 & Site 5 & Site 6 & Site 7 & Site 8 & Site 9 & Site 10 & Site 11 & Site 12 & Site 13 & Site 14 & Site 15 & Site 16 & Site 17 & C.E.C \\
\hline P.a.f & $! 4.24$ & ! 12.7 & $! 17.1$ & ! 10.2 & ! 7.37 & ! 5.41 & ! 10.1 & ! 12.7 & ! 11.1 & ! 8.37 & ! 17.9 & ! 8.43 & ! 11.2 & ! 13.0 & ! 13.7 & ! 11.6 & ! 13.0 & \\
\hline $\mathrm{Fe}_{2} \mathrm{O}_{3}$ & 23.4 & 42.1 & 30.1 & 22.9 & 30.6 & 20 & 15.8 & 18 & 26.2 & 9.78 & 21.8 & 19.1 & 36 & 19.9 & 22.4 & 23.7 & 24.5 & 5.00 \\
\hline $\mathrm{MgO}$ & 0.288 & 0.135 & 0.193 & 0.195 & 0.229 & 0.271 & 0.202 & 0.208 & 0.211 & 0.299 & 0.367 & 0.238 & 0.258 & 0.413 & 0.352 & 0.467 & 0.264 & 2.00 \\
\hline $\mathrm{CaO}$ & 0.26 & 0.22 & 0.372 & 0.151 & 0.438 & 0.389 & 0.61 & 0.0953 & 0.517 & 0.796 & 0.18 & 0.167 & 0.382 & 0.197 & 0.0604 & 0.41 & 2.3 & 3.63 \\
\hline $\mathrm{Al}_{2} \mathrm{O}_{3}$ & 12.6 & 15.1 & 12.9 & 18.1 & 14 & 15.9 & 18.4 & 22.9 & 17.3 & 14.1 & 17.8 & 19.9 & 11.2 & 15.9 & 19.6 & 15.2 & 15.6 & 8.10 \\
\hline $\mathrm{TiO}_{2}$ & 4.35 & 3.25 & 2.63 & 4.03 & 4.14 & 2.72 & 2 & 1.54 & 1.65 & 1.34 & 1.91 & 2.39 & 1.8 & 1.68 & 2.09 & 2.17 & 2.12 & 0.44 \\
\hline $\mathrm{MnO}_{2}$ & n.d & n.d & 18.6 & 0.232 & 0.365 & n.d & n.d & n.d & 0.331 & 0.249 & 8 & n.d & 14.3 & 10.5 & 6.83 & 3.65 & 7.86 & 0.10 \\
\hline $\mathrm{P}_{2} \mathrm{O}_{5}$ & 0.366 & 0.099 & 0.192 & 0.17 & 0.201 & 0.313 & 0.134 & 0.0916 & 0.13 & 0.243 & 0.173 & 0.174 & 0.099 & 0.196 & 0.129 & 0.136 & 0.297 & 0.11 \\
\hline $\mathrm{SiO}_{2}$ & 51.2 & 24.8 & 16.2 & 42.1 & 39.6 & 50.8 & 51.7 & 43.2 & 41.2 & 62.5 & 29.8 & 47.7 & 21.8 & 35.8 & 32.6 & 39.8 & 31.8 & 27.70 \\
\hline
\end{tabular}

P.a.f: loss on fire; n.d: not detected; ! : set values below detection limits; CEC: crude earth content. 
The concentrations of the elements (in $\mathrm{mg} / \mathrm{kg}$ dry mass) taking into account the dilution factor and the conversion factor are reported in Table 5 and Table 6.

The soil nutrient concentrations (in $\mathrm{mg} / \mathrm{kg}$ ) vary from $(31,400$ - 3080) for $\mathrm{K}$, (5620 - 1630) for Mg, (3200 - 800) for P, (33,000 - 862) for $\mathrm{Ca},(1592$ - 874) for $\mathrm{S}$

Table 4. Concentration (in \%) of trace elements in agricultural soils of Moanda.

\begin{tabular}{|c|c|c|c|c|c|c|c|c|c|c|c|c|c|c|c|c|c|}
\hline & Site 1 & Site 2 & Site 3 & Site 4 & Site 5 & Site 6 & Site 7 & Site 8 & Site 9 & Site 10 & Site 11 & Site 12 & Site 13 & Site 14 & Site 15 & Site 16 & Site 17 \\
\hline I & 0.109 & 0.114 & n.d & 0.101 & 0.2 & 0.198 & 0.0538 & n.d & 0.0703 & & 0.0359 & 0.0678 & n.d & 0.0476 & 0.0358 & n.d & 0.0728 \\
\hline $\mathrm{NiO}$ & 0.667 & n.d & n.d & n.d & n.d & 0.794 & 0.331 & 0.173 & n.d & 0.377 & n.d & 0.24 & n.d & n.d & n.d & 0.254 & n.d \\
\hline $\mathrm{ZrO}_{2}$ & 0.455 & 0.592 & 0.318 & 0.705 & 0.99 & 0.542 & 0.23 & 0.18 & 0.226 & 0.374 & 0.167 & 0.304 & 0.293 & 0.237 & 0.184 & 0.259 & 0.362 \\
\hline $\mathrm{Nb}_{2} \mathrm{O}_{5}$ & 0.159 & 0.189 & 0.105 & 0.181 & 0.244 & 0.211 & n.d & 0.0663 & n.d & n.d & 0.0576 & 0.118 & 0.123 & 0.0627 & 0.0641 & 0.0828 & 0.12 \\
\hline $\mathrm{Cr}_{2} \mathrm{O}_{3}$ & 0.117 & n.d & n.d & n.d & n.d & n.d & n.d & n.d & n.d & n.d & n.d & n.d & n.d & n.d & n.d & n.d & n.d \\
\hline $\mathrm{SrO}$ & 0.106 & 0.114 & 0.0932 & 0.0933 & 0.135 & 0.169 & n.d & 0.0287 & n.d & n.d & 0.0484 & 0.0738 & 0.106 & 0.0545 & 0.0457 & 0.067 & 0.0896 \\
\hline Ac & 0.0927 & n.d & 0.0712 & 0.0878 & n.d & 0.14 & n.d & n.d & n.d & n.d & 0.029 & 0.0682 & 0.0822 & 0.0399 & 0.0356 & 0.0528 & 0.085 \\
\hline $\mathrm{Rb}$ & 0.0649 & 0.0672 & 0.0492 & 0.0605 & 0.0624 & 0.108 & n.d & 0.0197 & n.d & 0.0174 & 0.0435 & 0.0506 & 0.101 & 0.0535 & 0.0431 & 0.0635 & 0.0592 \\
\hline $\mathrm{ThO}_{2}$ & n.d & 0.138 & n.d & n.d & n.d & n.d & n.d & n.d & n.d & n.d & n.d & n.d & n.d & n.d & n.d & n.d & n.d \\
\hline $\mathrm{BaO}$ & 0.241 & n.d & 0.248 & n.d & n.d & n.d & n.d & n.d & n.d & n.d & 0.119 & n.d & 0.373 & 0.19 & 0.155 & n.d & n.d \\
\hline $\mathrm{SO}_{3}$ & 0.199 & 0.109 & 0.128 & 0.164 & 0.187 & 0.191 & 0.167 & 0.153 & 0.123 & 0.162 & 0.191 & 0.113 & 0.113 & 0.139 & 0.127 & 0.114 & 0.158 \\
\hline $\mathrm{Y}_{2} \mathrm{O}_{3}$ & n.d & n.d & 0.07 & 0.113 & 0.149 & n.d & n.d & n.d & n.d & n.d & 0.0432 & 0.073 & 0.0947 & 0.0538 & 0.0469 & 0.0675 & 0.0771 \\
\hline $\mathrm{CuO}$ & n.d & n.d & n.d & n.d & n.d & n.d & n.d & n.d & n.d & n.d & n.d & n.d & 0.069 & n.d & n.d & 0.0442 & n.d \\
\hline $\mathrm{ZnO}$ & n.d & n.d & 0.0942 & n.d & n.d & n.d & 0.0574 & n.d & n.d & n.d & n.d & n.d & n.d & 0.0474 & n.d & n.d & 0.0663 \\
\hline $\mathrm{Na}_{2} \mathrm{O}$ & n.d & n.d & 0.0776 & n.d & 0.138 & n.d & n.d & n.d & 0.112 & 0.136 & n.d & n.d & n.d & n.d & 0.0683 & n.d & n.d \\
\hline $\mathrm{CoO}$ & n.d & n.d & 0.0849 & n.d & n.d & n.d & n.d & n.d & n.d & n.d & 0.0424 & n.d & n.d & n.d & n.d & n.d & n.d \\
\hline
\end{tabular}

P.a.f: loss on fire; n.d: not detected; !: Fixed/<<: lower to the limits detection.

Table 5. Concentration of nonmetallic elements (in $\mathrm{mg} / \mathrm{kg}$ ) in Moanda dry agricultural soils.

\begin{tabular}{|c|c|c|c|c|c|c|c|c|c|c|c|c|c|c|c|c|c|}
\hline & Site 1 & Site 2 & Site 3 & Site 4 & Site 5 & Site 6 & Site 7 & Site 8 & Site 9 & Site 10 & Site 11 & Site 12 & Site 13 & Site 14 & Site 15 & Site 16 & Site 17 \\
\hline $\mathrm{O}$ & 924,000 & 882,000 & 894,000 & 952,000 & 902,000 & 936,000 & 994,000 & 990,000 & 948,000 & $1,012,000$ & 964,000 & 964,000 & 852,000 & 946,000 & 946,000 & 942,000 & 924,000 \\
\hline $\mathrm{K}$ & 16,700 & 3080 & 8420 & 7920 & 15,400 & 29,000 & 4300 & 11,940 & 13,360 & 21,000 & 22,200 & 13,280 & 26,600 & 24,400 & 23,400 & 31,400 & 19,800 \\
\hline $\mathrm{P}$ & 3200 & 864 & 1676 & 1484 & 1752 & 2740 & 1166 & 800 & 1132 & 2120 & 1508 & 1518 & 862 & 1714 & 1122 & 1192 & 2580 \\
\hline$S$ & 1592 & 874 & 1024 & 1310 & 1494 & 1530 & 1338 & 1222 & 988 & 1296 & 1530 & 902 & 908 & 1114 & 1014 & 914 & 1262 \\
\hline I & 2180 & 2280 & n.d & 2020 & 4000 & 3960 & 1076 & n.d & 1406 & n.d & 718 & 1356 & n.d & 952 & 716 & n.d & 1456 \\
\hline $\mathrm{Sr}$ & 1784 & 1940 & 1576 & 1578 & 2280 & 2860 & n.d & 484 & n.d & n.d & 818 & 1248 & 1786 & 922 & 772 & 1134 & 1514 \\
\hline $\mathrm{Mg}$ & 3460 & 1630 & 2320 & 2360 & 2760 & 3280 & 2440 & 2500 & 2540 & 3600 & 4420 & 2860 & 3100 & 4980 & 4240 & 5620 & 3180 \\
\hline $\mathrm{Na}$ & n.d & n.d & 1152 & n.d & 2040 & n.d & n.d & n.d & 1666 & 2020 & n.d & n.d & n.d & n.d & 1014 & n.d & n.d \\
\hline $\mathrm{Ba}$ & 4320 & n.d & 4440 & n.d & n.d & n.d & n.d & n.d & n.d & n.d & 2140 & n.d & 6680 & 3400 & 2780 & n.d & n.d \\
\hline $\mathrm{Si}$ & 478,000 & 232,000 & 151,000 & 394,000 & 370,000 & 476,000 & 484,000 & 404,000 & 38,6000 & 584,000 & 278,000 & 446,000 & 204,000 & 334,000 & 304,000 & 372,000 & 298,000 \\
\hline $\mathrm{Ca}$ & 3700 & 3140 & 5320 & 2160 & 6260 & 5560 & 8720 & 1362 & 7380 & 11380 & 2560 & 2380 & 5460 & 2820 & 862 & 5860 & 33,000 \\
\hline $\mathrm{Rb}$ & n.d & 1344 & n.d & 1210 & 1248 & n.d & n.d & n.d & n.d & 348 & n.d & 1012 & n.d & n.d & 862 & n.d & n.d \\
\hline
\end{tabular}

n.d: not detected; <<: lower to the limits detection. 
Table 6. Concentration of metallic elements (in $\mathrm{mg} / \mathrm{kg}$ ) in Moanda dry agricultural soils.

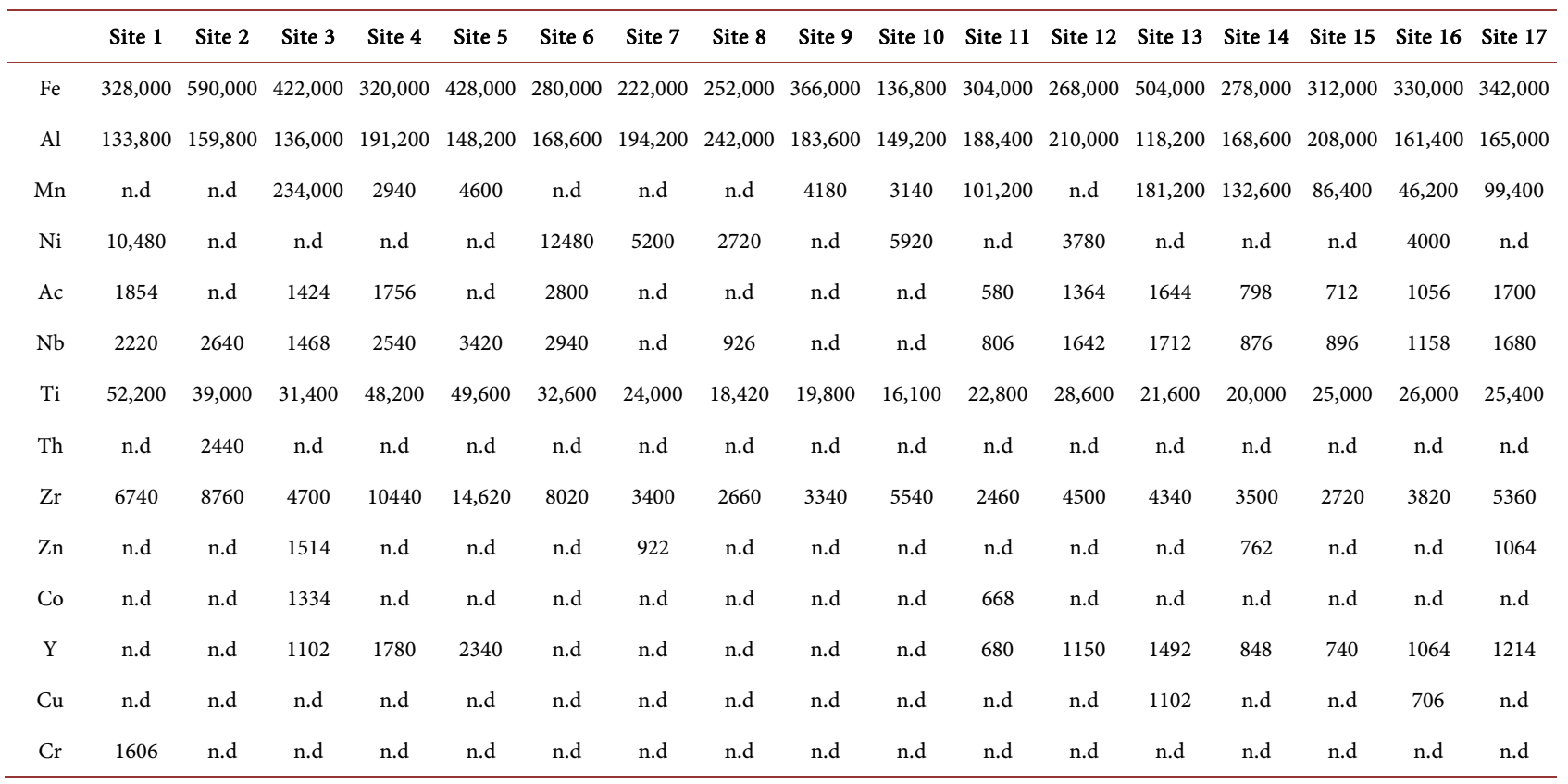

n.d: not detected; <<: lower to the limits detection.

and $(2040$ - 1014) for $\mathrm{Na}$ at the sites detected. The average total concentrations of the elements $\mathrm{K}(17,188.24), \mathrm{Mg}$ (3252.35), $\mathrm{Ca}$ (6348.47059), are higher than the average concentrations of its elements observed in the soils cultivated around Moanda by the extraction method and of mineralization in the work (Ondo et al.) [21]-For Ca (178.6 $\pm 24.8 \mathrm{~b}), \mathrm{Mg}(1.037 \pm 430 \mathrm{~b}), \mathrm{k}(8.796 \pm 785 \mathrm{~b})$. Only the $\mathrm{Na}(464.24)$ in our samples is lower than the $\mathrm{Na}(891.1 \pm 47.2 \mathrm{a})$ of the soils cultivated in the previous works.

The average concentrations of metallic trace elements (in $\mathrm{mg} / \mathrm{kg}$ dry mass) in the Moanda agricultural soil layers between $(0-15 \mathrm{~cm})$ were decreasing values for Fe (334,282.35), Al (172,129.41), Mn (5583.53), Ni (2622.35), Nb (1466.12), Ac (922.82), Y (730), Zn (250.71), Th (143.53), Co (117.76), Cu (106.35), Co (94.47). A comparative study was carried out with the critical threshold toxicity standards recommended for its components to ensure the safety of agricultural products (Table 7).

The average concentrations of $\mathrm{Cu}, \mathrm{Fe}, \mathrm{Mn}, \mathrm{Zn}, \mathrm{Ni}$, Co are well above the critical toxicity limits recommended for these elements for a safety of agricultural products which are $(8-40 \mathrm{mg} / \mathrm{kg})$ for $\mathrm{Cu},(10-50 \mathrm{mg} / \mathrm{kg})$ for $\mathrm{Fe},(200-1000 \mathrm{mg} / \mathrm{kg})$ for $\mathrm{Mn},(10-100 \mathrm{mg} / \mathrm{kg})$ for $\mathrm{Zn},(10-100 \mathrm{mg} / \mathrm{kg})$ for Ni, $(15-50 \mathrm{mg} / \mathrm{kg})$ for Co [22]. These elements can cause phytotoxicity if their bioaccumulation is significant in plants grown in this region. However, we must qualify because the toxicity of an element depends among other things on its speciation, influenced by factors related to the soil ( $\mathrm{pH}$, redox potential, cation exchange capacity), to the plant (species, variety, stage of development, root excretion) and in the soil microorganisms (biological activity), climate (temperature, humidity), cultivation techniques, element speciation and interactions between elements. It would be 
difficult to assess the health impact from toxicological threshold values from often disparate publications [23].

\section{Mineralogical distribution in the soils of Moanda}

The distribution of the main metallic trace elements presenting pollution risks in the agricultural soils of Moanda (Figure 2) shows a preponderant accumulation

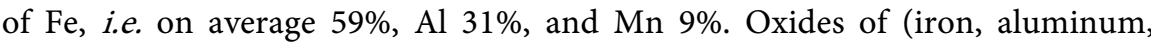
manganese, silica) and clay minerals (kaolinite) are the main minerals abundant in the ferralitic soils characteristic of Moanda soil [24]. The Ni content is $1 \%$ while $\mathrm{Cu}, \mathrm{Cr}$, Co are less than $1 \%$.

Moanda's soil is relatively acidic, with a relatively $\mathrm{pH}<5$ Ondo et al. [21], these soils will enhance the assimilation of certain soluble elements compared to other. The $\mathrm{Mn}, \mathrm{Fe}, \mathrm{Cu}$ and $\mathrm{Zn}$ will be the main trace elements which will be assimilated more easily according to their bioavailability [19].

The detrimental effects of soil acidity on plant physiology and yield reductions are generally attributed to the presence of soluble aluminum and/or in some soils, to that of soluble manganese [25]. The toxicity of aluminum is most often indirect

Table 7. Critical micronutrient levels in soils.

\begin{tabular}{cccc}
\hline \multicolumn{3}{c}{ Critical content in soils $(\mathrm{mg} / \mathrm{kg})$} & Moanda soil \\
\hline Elements & Deficiency & Toxicity & Mean content $(\mathrm{mg} / \mathrm{kg})$ \\
\hline $\mathrm{B}$ & 10 & $50-200$ & - \\
$\mathrm{Cu}$ & $3-5$ & $20-100$ & 106.35 \\
$\mathrm{Fe}$ & 50 & 1000 & $334,282.35$ \\
$\mathrm{Mn}$ & $10-20$ & $300-500$ & $52,697.65$ \\
$\mathrm{Mo}$ & 0.1 & $10-50$ & - \\
$\mathrm{Zn}$ & $15-20$ & $100-400$ & 250.71 \\
$\mathrm{Ni}$ & $1-5$ & $10-100$ & 2622.35 \\
$\mathrm{Co}$ & 0.2 & $15-50$ & 117.76 \\
\hline
\end{tabular}

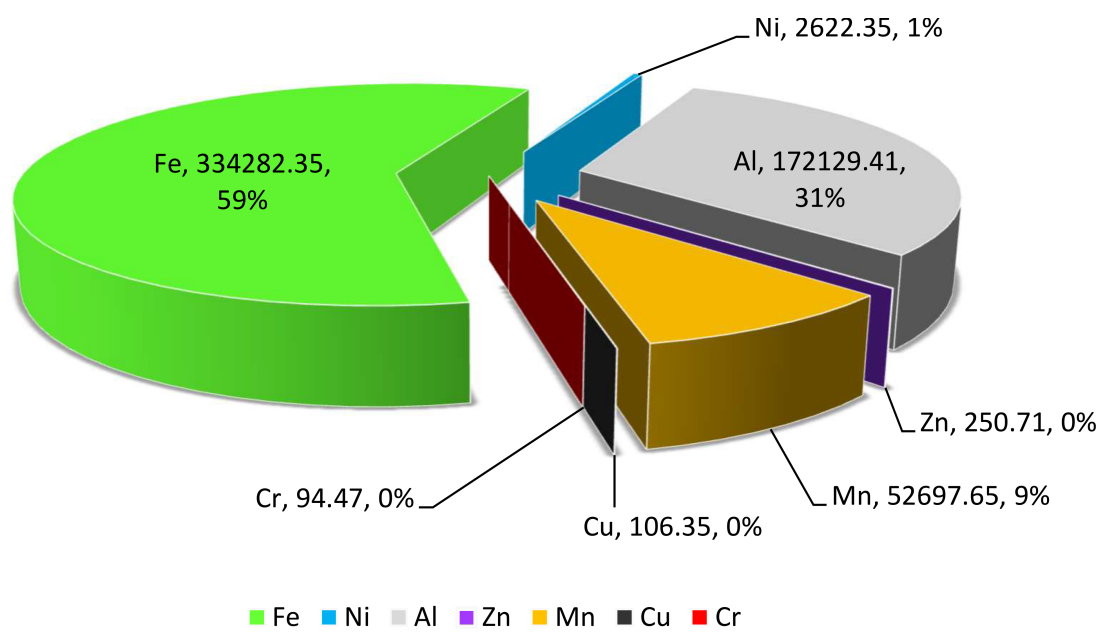

Figure 2. Distribution of the main trace elements found in Moanda dry agricultural soils. 
because aluminum disrupts the water supply of plants, inhibits the absorption of phosphorus and calcium and, on the contrary, enhances that of manganese [26].

Mn can quickly become the most available element for cultivated plants in these soils dedicated to agriculture (Anguile et al., 2013) [27].

These data show the major environmental stake of this study of the evolution of these trace elements in the agricultural soils of Moanda.

In order to judge the homogeneity on the spatial distribution of the chemical elements present in the soil samples from the point of view of the concentrations for each element, a simple comparison of the dispersion parameters (maximum content, minimum content, mean and standard deviation) was initially allowed to judge the homogeneity of our samples (Table 8).

The very high values of the standard deviations reflect the significant

Table 8. Relative statistical results to the variability of soils.

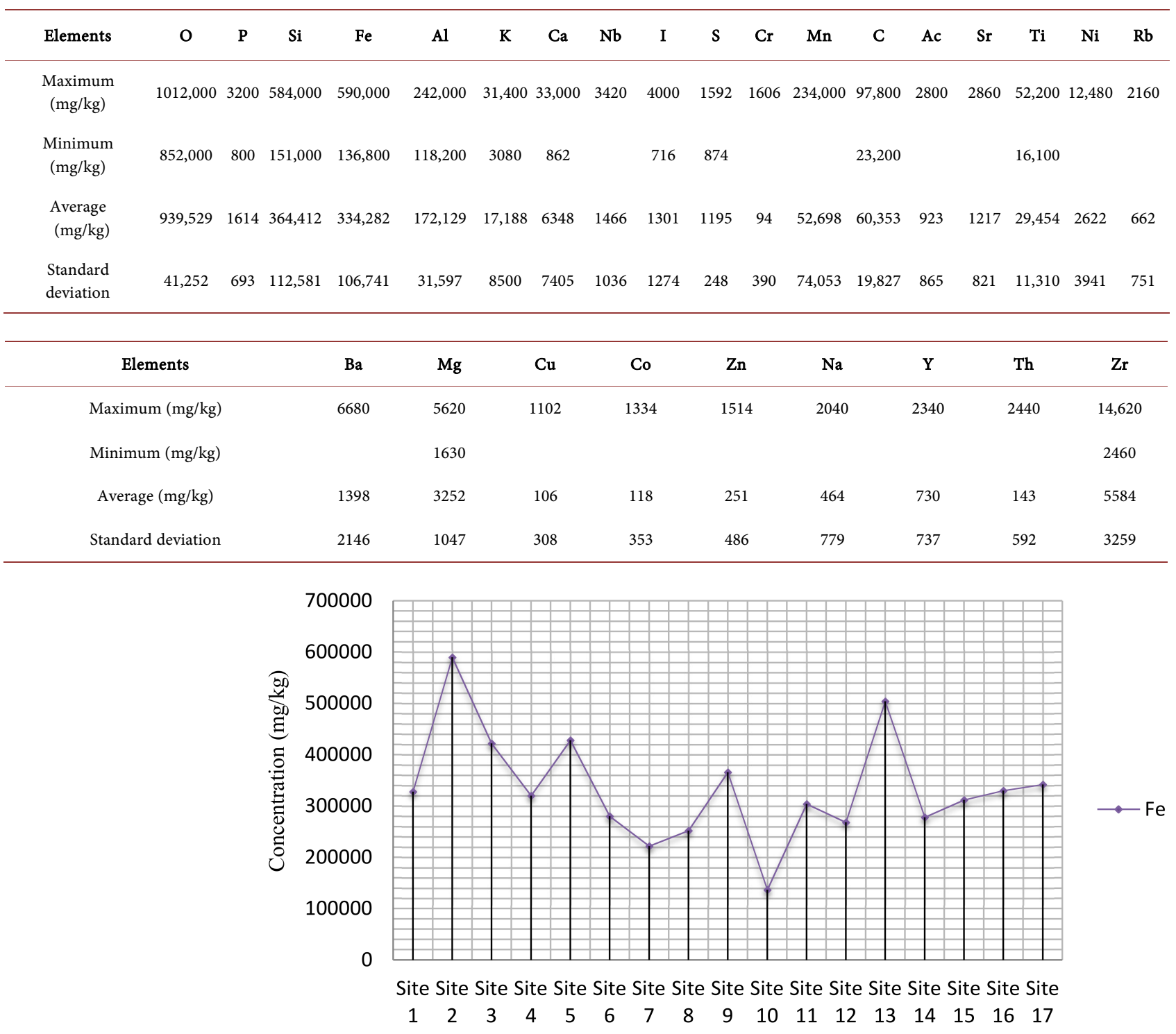

Figure 3. Distribution of Fe in the 17 agricultural soils sites of Moanda. 
dispersiveness of the soils with the concentrations of the elements varying considerably from one site to another. Thus, for $\mathrm{O}, \mathrm{Al}, \mathrm{Fe}, \mathrm{Si}$ and $\mathrm{Mn}$, the concentrations vary respectively by $\pm 41,252$, i.e. $2 . \%$; $\pm 31,597$ or $(2 \%) ; \pm 106,741$ or $(5 \%) ; \pm 112,581$ or $(6 \%) ; \pm 74,053$ or $(4 \%)$ around their respective averages. For the rest of the elements, there is little variability, i.e. values less than $1 \%$ from one site to another compared to the average.

These data reflect the dispersive nature of the distribution of chemical elements in the composition of soils from one site to another in the same region. Figures 3-7 illustrate the distribution of the elements $\mathrm{Mn}, \mathrm{Ni}, \mathrm{Fe}, \mathrm{Al}$ and $\mathrm{Zn}$ in the soil samples.

A high availability of these ETMs in general and of $\mathrm{Mn}$ in particular in the soil solution would present a real risk on the food security of agricultural products from this region.

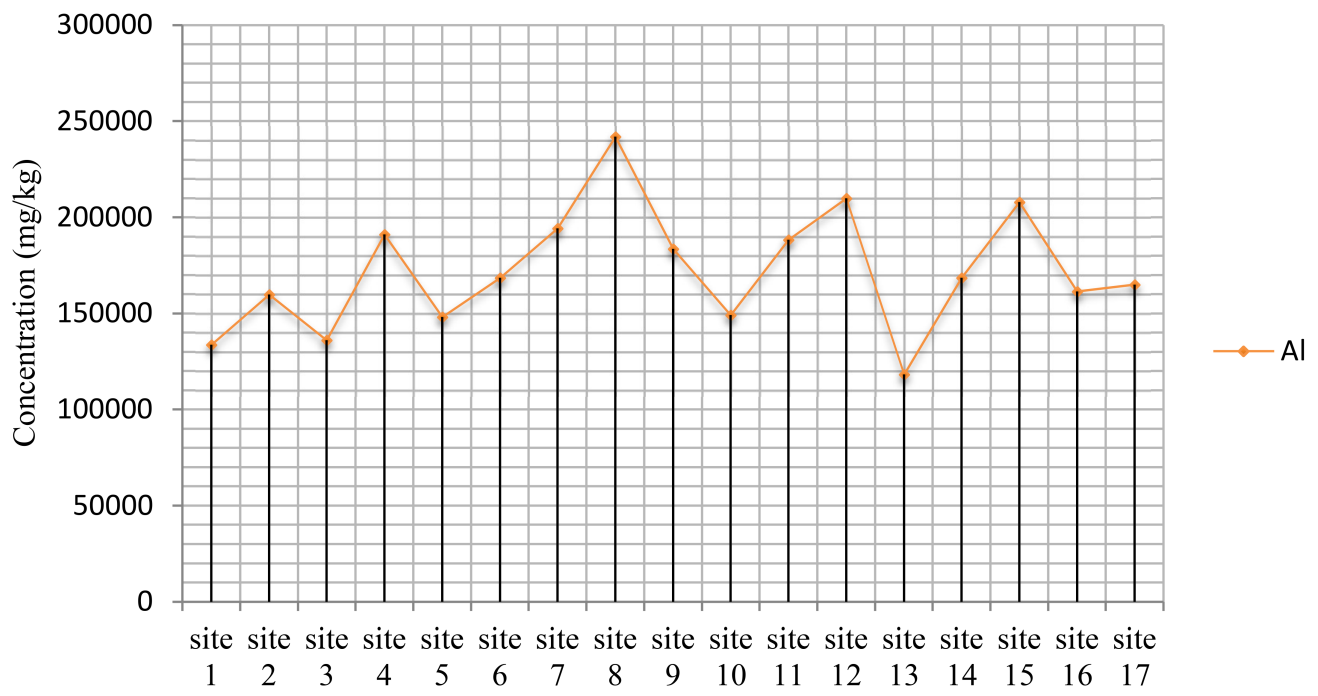

Figure 4. Distribution of $\mathrm{Al}$ in the 17 agricultural soils sites of Moanda.

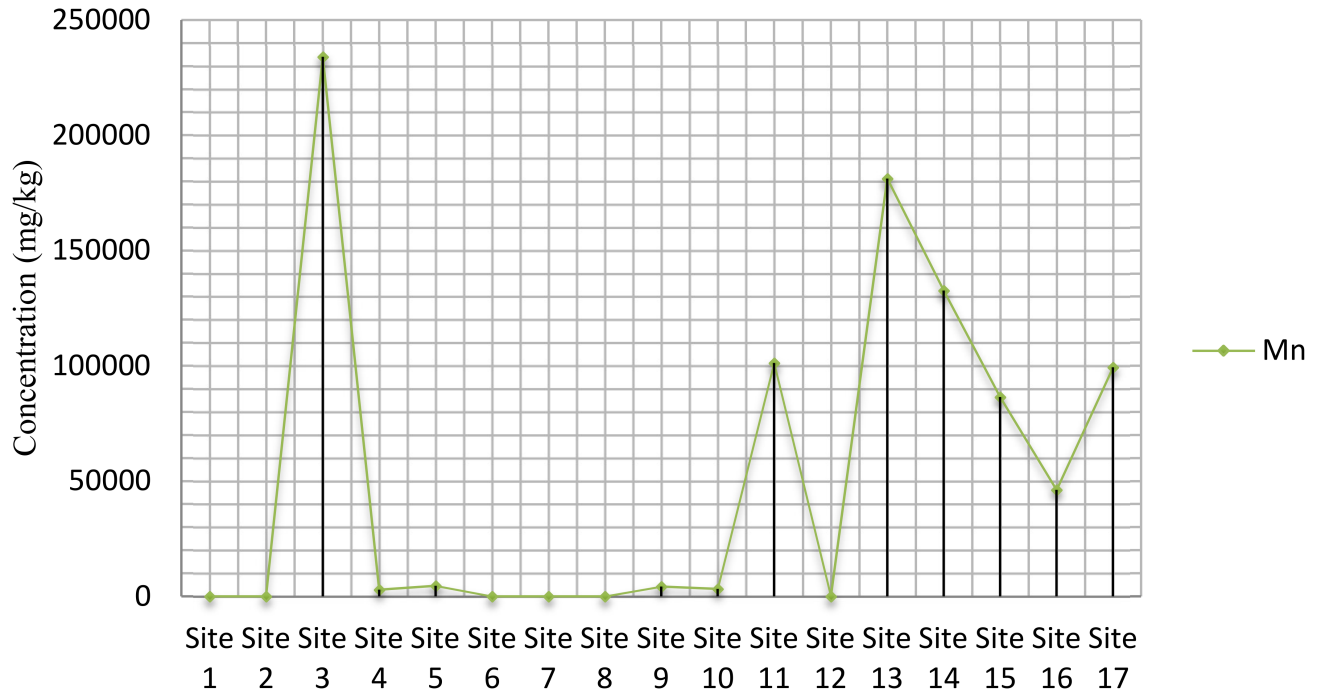

Figure 5. Distribution of Mn in the 17 agricultural soils sites of Moanda. 


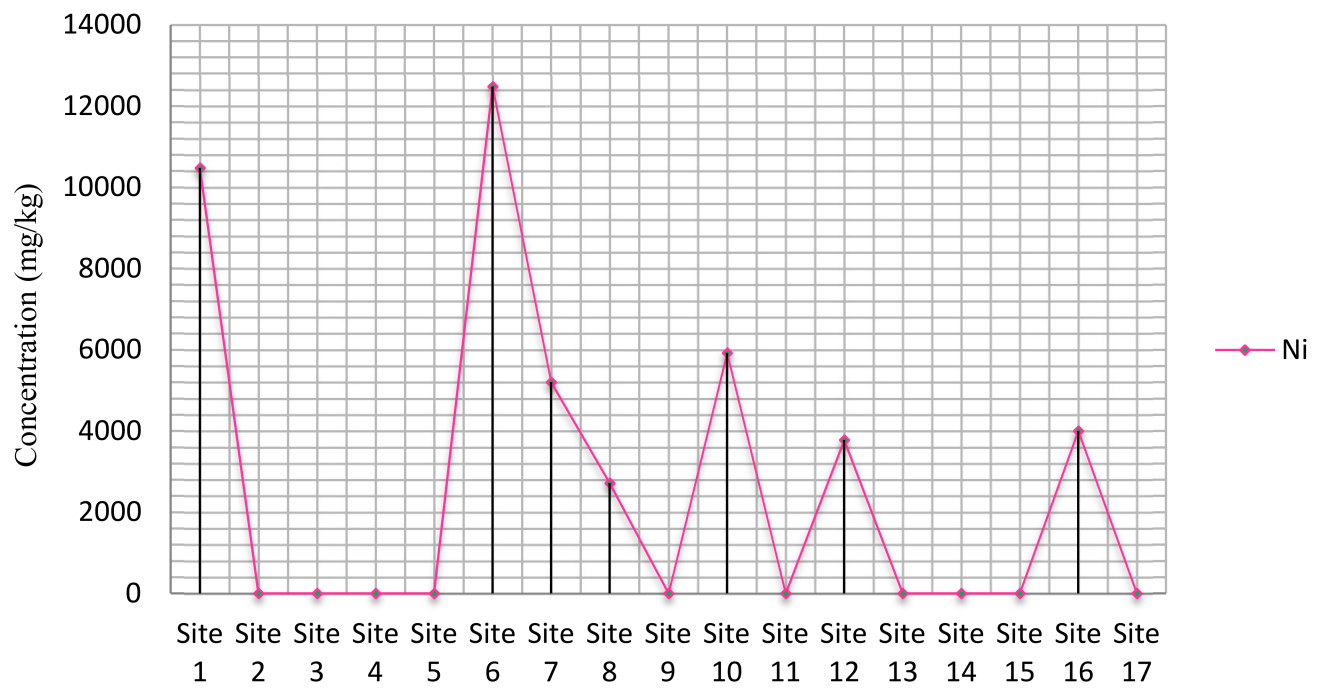

Figure 6. Distribution of $\mathrm{Ni}$ in the 17 agricultural soils sites of Moanda.

\section{Conclusions}

The analysis of the chemical composition of soils by X-ray fluorescence with wavelength dispersion shows the effectiveness of this analytical technique from a qualitative and quantitative point of view because it has revealed the presence of 27 elements in the soils. sampled in Moanda: $\mathrm{O}, \mathrm{Si}, \mathrm{Fe}, \mathrm{Al}, \mathrm{C}, \mathrm{Mn}, \mathrm{Ti}, \mathrm{K}, \mathrm{Ca}, \mathrm{Zr}$, $\mathrm{Mg}, \mathrm{Ni}, \mathrm{P}, \mathrm{Nb}, \mathrm{I}, \mathrm{Sr}, \mathrm{S}, \mathrm{Ba}, \mathrm{Rb}, \mathrm{Ac}, \mathrm{Y}, \mathrm{Na}, \mathrm{Zn}, \mathrm{Th}, \mathrm{Co}, \mathrm{Cu}$ and $\mathrm{Cr}$.

Among the elements, the main ions essential for the efficiency of agricultural production are: $\mathrm{Ca}, \mathrm{Mg}, \mathrm{K}, \mathrm{Na}, \mathrm{P}$ and $\mathrm{S}$. Trace elements are: $\mathrm{Fe}, \mathrm{Al}, \mathrm{Mn}, \mathrm{Cu}, \mathrm{Ni}$, $\mathrm{Cr}$ and $\mathrm{Co}$. The set of dispersive parameters around the mean showed heterogeneity in the chemical composition of soils in a given region.

The concentration levels of the trace metal elements $\mathrm{Cu}, \mathrm{Fe}, \mathrm{Al}, \mathrm{Mn}, \mathrm{Zn}, \mathrm{Ni}$, $\mathrm{Cr}$ and Co found in agricultural soils of Moanda are above the critical toxicity limits recommended for the safety of agricultural products.

Moanda soils, being relatively acidic, will promote the assimilability of soluble $\mathrm{Mn}$ in soils rich in manganese ore as is the case in the Moanda region and increase the risk of toxicity to crops. The risk of manganese poisoning is very real in the mining town of Moanda. The practice of agriculture remains a concern for food security.

The lack of previous data did not allow us to estimate increases in soil levels as a result of human action. A periodic assessment as part of a monitoring program will show the evolution of metals, accidental pollution and chronic pollution corresponding to the impact of mining activity.

\section{Acknowledgements}

The authors thank the National Center for Scientific and Technological Research Division UATRS of Morocco for having accepted to analyze these samples, the research team of the Inorganic Materials Chemistry Laboratory (L.A.C.M.I.) for the efforts made to carry out this work as well as all the farmers who accepted the sam- 
pling of the fields all the people who contributed to the realization of this work.

\section{Conflicts of Interest}

The authors declare no conflicts of interest regarding the publication of this paper.

\section{References}

[1] Direction générale du Trésor, Ministère de l'Economie, des Finances et de la Relance (2021).

[2] Koumba, C. (2014) La gestion et l'exploitation des ressources naturelles au Gabon: vers une réorganisation spatiale des activités productives. Les Cahiers d Outre-Mer, 256 p.

[3] Poulard, F., Daupley, X., Didier, C., Pokryska, Z., D’Hugues, P., Charles, N., Dupuy, J.-J. andSave, M. (2017) Exploitation minière et traitement des minerais. Collection "La mine en France". Tome 6, 77 p., 43 fig., 2 ann.

[4] Gérard, M. (2001) Rapport sur les effets des métaux lourds sur l'environnement et la santé. Office Parlementaire D’évaluation Des Choix Scientifiques Et Technologique, $366 \mathrm{p}$.

[5] Jolivet, C., Arrouays, D., Boulonne, L., Ratié, C. and Saby, N. (2006) Le Réseau de Mesures de la Qualité des Sols de France (RMQS) Etat d'avancement et premiers resultants. Etude et Gestion des Sols, 13, 149-164.

[6] Maghe-Chauvin, S. and Sauzay, N. (2014) Caractérisation de la pollution par mesure intégrative grâce aux DGT dans les eaux souterraines, MINELIS, $3^{\mathrm{e}}$ Rencontre nationales de la recherche sur les sites et sols pollués, session de posters 18 et 19 , Paris.

[7] Faye, M.M. (2012) Cadre de gestion environnementale et sociale (cges). Projet CAB4 CITGB, Central African Backbone République Gabonaise.

[8] Okanga-Guay M.J. (2008) Moanda, Gabon: Ville minière ou ville régionale. Mémoire de Maître ès sciences en géographie. $48 \mathrm{p}$

[9] Sy Abdoul Aziz, M.H. and Houssou, M. (2008) Diagnostic du système national de recherche et de vulgarisation agricoles du Gabon, et stratégie de renforcement des capacités pour la dissémination des connaissances et des technologies agricoles. Food and Agriculture Organization of the United Nations, 77 p.

[10] Eramet (2019) “Essentiel, Tout un Monde, Au Gabon” Brochure. Moanda, 27 p. https://comilog.eramet.com/

[11] Mengue Edoh Afiyo, G.M. (2011) Impacts de l'exploitation minière su l'environnement et les collectivités locales dans la province du haut-Ogooué: Cas de la Comilog à Moanda (Gabon). Mémoire de Master Gestion durable des mines, 48 p.

[12] Le conseil canadien des ministres de l'environnement (1993) Guide d'échantillonnage, l'analyse des échantillons et la gestion des données des lieux contaminées Vol I: Rapport principal. 80 p.

[13] Mench, M. and Baize, D. (2004) Contamination des sols et de nos aliments d'origine végétale par les éléments en traces. Le Courrier de Penvironnement de P INRA, 52, 31-56.

[14] Reid, K. (2006) Fiche technique, échantillonnage et analyse de sol dans le cadre de la gestion des éléments nutritifs. 8 p.

[15] Bashangwa Mpozi, B. (2015) Analyse des contraintes de développement du fruit de la passion au Burundi. Cas de la commune Matongo province Kayanza. XXX ${ }^{\text {es }}$ Journées 
sur le Développement Ethique, entrepreneuriat et développement. Les Cahiers de PAssociation Tiers-Monde, No. 30, 191-200.

[16] Sabouang, J.F. (2007) Investigation sur la trace minérale et les risques de contamination par les métaux lourds contenus dans les feuilles de Gnetum africanum et Gnetum buchholzianum récoltées au Sud Cameroun. Thèse de Doctorat, Université de Yaoundé I, Cameroun, $131 \mathrm{p}$.

[17] Rakotondrajoa, A. (2008) Utilisation de la régression PLS en spectroscopie XRF: Développement d'un logiciel d'analyse quantitative et applications à la spectrométrie XRF à Réflexion Totale. Thèse de doctorat, Université d'Antananarivo, Madagascar, $117 \mathrm{p}$.

[18] Messi Me Ndong, A.N. (2018) Contribution à l'étude d'impact des éléments traces métalliques sur les plantes alimentaires de la ville minière de Moanda (Gabon). Cas du Manihot esculenta Crantz. Thèse de Doctorat, Université des Sciences et Techniques de Masuku, Franceville, $132 \mathrm{p}$.

[19] Tremel-Schaub, A. and Feix, I. (2005). Contamination des sols. Transferts des sols vers les plantes. EDPS Sciences, ADEME (Agence de la transition écologique), 407 p.

[20] Temgoua, E., Ntangmo Tsafack, H., Pfeifer, H-R. and Njine, T. (2015) Teneurs en éléments majeurs et oligoéléments dans un sol et quelques cultures maraîchères de la ville de Dschang, Cameroun. African Crop Science Journal, 23, 35-44.

[21] Ondo, J.A., Biyogo, R.M., Eba, F., Prudent, P., Fotio, D., Ollui-Mboulou, M. and Omva-Zue, J. (2013) Accumulation of Soil Borne Aluminium, Iron, Manganese and Zinc in Plants Cultivated in the Region of Moanda (Gabon) and Nutritional Characteristics of the Edible Parts Harvested. Journal of the Science of Food and Agriculture, 10, 2549-2555. https://doi.org/10.1002/jsfa.6074

[22] Pasquier, L. (1963) Guide du sol "Largile et Lamotte". ENESAD—Unité Informatique Pédagogique.

[23] Colinet, G. (2003) Eléments traces métalliques dans les sols. Contribution à la connaissance des déterminants de leur distribution spatiale en région limoneuse Belge. Thèse doctorat, Faculté Universitaire des Sciences Agronomiques de Gembloux, Belgique, $139 \mathrm{p}$.

[24] Buol, S.W. and Eswaran, H. (1999) Oxisols. Advances in Agronomy, 68, 151-195. https://doi.org/10.1016/S0065-2113(08)60845-7

[25] Van Lierop, W. (1990) Soil pH and Lime Requirement Determination. In: Westerman, R.L., Ed., Soil Testing and Plant Analysis, Vol. 3, Soil Science Society of America, Madison, 73-126. https://doi.org/10.2136/sssabookser3.3ed.c5

[26] Boyer, J. (1976) L'aluminium échangeable: Incidences agronomiques, évaluation et correction de sa toxicité dans les sols tropicaux. Cahiers ORSTOM, séries Pédologique, 14, 259-269.

[27] Anguilé, J.J., Makani, T., Nemba, R.M., Messi Me Ndong, A.N. (2013) Mineral Uptake in the Leaves of Manihot esculenta Crantz Harvested in Moanda (Gabon) and Assessment of Potential Health Risks for Populations. Journal of Environmental Science, Computer Science and Engineering \& Technology, 2, 1204-1212. 


\section{Abbreviations}

ETM: Metallic Trace Element.

ICP/MS: Plasma couplé à un système d'induction hautes fréquences/spectromètre de masse (Plasma coupled to a high frequency induction system/mass spectrometer).

UATRS: Unités d'Appui Technique à la Recherche Scientifique (Scientific Research Technical Support Units). 